\title{
CARBÚNCULO SINTOMÁTICO EM RUMINANTES: MEDIDAS DE DIAGNÓSTICO, PROFILAXIA E CONTROLE
}

\author{
SANTOS, Sthefany Kamile dos ${ }^{1}$ \\ PADILHA, Joselaine Bortolanza ${ }^{2}$ \\ MELLO, Diessyca de ${ }^{1}$ \\ LEÃO, Guilherme Fernando Mattos ${ }^{3}$ \\ NORILER, Elaine Pasqualin ${ }^{4}$ \\ FALBO, Margarete Kimie ${ }^{5}$ \\ TEIXEIRA, Pedro Paulo Maia ${ }^{6}$
}

RESUMO: O Carbúnculo Sintomático é uma clostridiose que acomete os ruminantes de todas as idades. Alguns animais podem apresentar sinais clínicos inespecíficos como febre, apatia e anorexia, ou sinais referentes ao sistema locomotor como rigidez muscular, claudicação, com inchaço subcutâneo e crepitação local no membro afetado, embora na maioria dos casos ocorra morte súbita. Várias ferramentas podem ser utilizadas para o diagnóstico desta enfermidade, mas todas apresentam empecilhos quanto à sua utilização, como ausência de sinais clínicos, devido ao curso agudo da doença, rapidez para realizar a avaliação da carcaça, bem como dificuldade do envio de amostras para isolamento. O tratamento do Carbúnculo Sintomático não é eficaz, e devido às características ambientais do agente, a prevenção da doença através de medidas de higienização e imunização são recomendadas para prevenir a ocorrência de casos numa propriedade. Diante do exposto, este trabalho tem como objetivo fazer uma breve revisão sobre as formas de diagnóstico, profilaxia e controle do Carbúnculo Sintomático.

Palavras-chave: Bovinos. Clostridioses. Prevenção. Ovinos.

\section{BLACKLEG IN RUMINANTS: DIAGNOSTIC, PREVENTION AND CONTROL MEASURES}

SUMMARY: The Blackleg is a clostridiose that affects all ages of ruminants. Some may show nonspecific clinical signs such as fever, lethargy and anorexia, or signals related to the musculoskeletal system such as stiffness, lameness with swelling and local subcutaneous sputtering on the affected limb, while the majority of cases sudden death occurs. Various tools can be used for the diagnosis of this disease, but all have drawbacks regarding their use, as the absence of clinical signs due to the acute course of the disease, quickly to carry out assessment of carcass, as well as difficulty of sending samples for isolation. Blackleg treatment is not effective, and due to environmental characteristics of the agent to disease prevention through immunization and hygienic measures are recommended to prevent the occurrence of cases in a property. Given the above, this paper aims to make a brief review of the forms of diagnosis, prevention and control of Blackleg.

Keywords: Cattle. Clostridiose. Prevention. Sheep.

\footnotetext{
${ }^{1}$ Médica Veterinária Mestranda em Ciências Veterinárias, Universidade Estadual do Centro-Oeste

${ }^{2}$ Médica Veterinária Mestranda em Zootecnia, Universidade Tecnológica Federal do Paraná

${ }^{3}$ Médico Veterinário, Msc. em Zootecnia, Doutorando em Zootecnia, Universidade Federal do Paraná

${ }^{4}$ Médica Veterinária

${ }^{5}$ Médica Veterinária Doutora em Processos Biotecnológicos, Professora de Graduação e do Programa de PósGraduação em Ciências Veterinárias, Universidade Estadual do Centro-Oeste

${ }^{6}$ Médico Veterinário Doutor em Reprodução Animal Professor da Universidade Federal do Pará
} 


\section{INTRODUÇÃO}

O Carbúnculo Sintomático (CS) caracteriza-se como uma doença infecciosa que também é conhecida popularmente como Peste da Manqueira. Ocorre comumente em bovinos, podendo ocorrer em ovinos, geralmente em épocas do ano mais quentes e em animais jovens, causando necrose muscular, toxemia grave, e alta mortalidade (MACHADO, 2008).

O CS é uma enfermidade aguda em bovinos e ovinos decorrente da multiplicação e produção de toxinas pelo agente anaeróbio Clostridium chauvoei na musculatura e tecido subcutâneo. Vários fatores como intervenções cirúrgicas, traumas, tosa, castração, corte da cauda, descorna, isquemias vasculares, tumores e outras infecções bacterianas podem desencadear infecções, uma vez que propiciam uma diminuição do oxigênio molecular, levando a um baixo potencial de óxido-redução nos tecidos (ASSIS et al., 2001; GREGORY et al., 2006). O Carbúnculo Sintomático é considerado uma doença "endógena" para bovinos e, na maioria dos casos, "exógena" para ovinos, sendo que em ambas as espécies é causada pelo Clostridium chauvoei (ASSIS et al., 2010).

O Carbúnculo Sintomático ocorre em ruminantes com bom estado nutricional, entre seis meses e três anos de idade, sendo que alguns animais apresentam sintomatologia clínica e outros, morte súbita (GOMES, 2013). De acordo com os informes anuais da Organização Internacional de Epizootias (OIE), descritos pelo Ministério da Agricultura, Pecuária e Abastecimento (MAPA), nos anos de 2005, 2006, 2007, 2008, 2009, 2010 e 2011 foram registrados 1342, 1159, 739, 669, 499, 604 e 8403 casos de Carbúnculo Sintomático em bovinos, respectivamente.

A ocorrência do CS acarreta queda na produção dos rebanhos, de tal forma, é evidente que para assegurar a boa produtividade a sanidade é um elo fundamental. Gregory et al. (2006) citam que as infecções por anaeróbios são provavelmente as mais negligenciadas das doenças bacterianas. As enfermidades causadas por microrganismos do gênero Clostridium ocasionam consideráveis perdas nos rebanhos, uma vez que o tratamento na maioria dos casos é impraticável (LOBATO et al., 2007), dessa forma boas práticas de higiene e a imunização contra essa enfermidade são medidas profiláticas extremamente importantes (ROGERS; SWECKER JR, 1997).

Diante do exposto, este trabalho tem por objetivo apresentar diretrizes para a identificação e diagnóstico do Carbúnculo Sintomático nos rebanhos, e principalmente ressaltar as medidas de profilaxia e controle desta doença, haja vista que seu tratamento muitas vezes é falho, e devido a características ecológicas do agente sua eliminação total da propriedade é impossível. 


\section{DIAGNÓSTICO}

Mesmo com um grande número de casos de Carbúnculo Sintomático relatados, o diagnóstico não é confirmado em laboratório, sendo realizado apenas com base nos achados clínicos e de necropsia (ASSIS et al., 2001).

Além da anamnese, sinais clínicos e achados de necrópsia, o exame histopatológico, isolamento dos agentes envolvidos e técnicas como imunofluorescência direta, imunohistoquímica e PCR (Polymerase chain reaction - reação em cadeia da polimerase) podem ser utilizados para dar suporte ao diagnóstico definitivo (LOBATO et al., 2007).

\section{Diagnóstico Clínico}

Inicialmente os sinais clínicos são de difícil observação, pois apresentam curso muito rápido, seguido de morte na maioria dos animais. Quando se observa sintomatologia clínica os sinais compreendem desde hipertermia, depressão, anorexia, estase ruminal a rigidez muscular seguida de claudicação. Os músculos dos membros posteriores, anteriores e lombares são os grupos musculares mais afetados. Há inchaço subcutâneo e crepitação local devido à produção de gás quando os músculos afetados são superficiais, tendendo a aumentar de tamanho, sendo inicialmente quente e dolorido, depois frio e indolor (STERNE, 1981).

Quando um membro é atingido, pode se observar dificuldade de locomoção devido à grande quantidade de gás produzida pela multiplicação bacteriana no foco de infecção, podendo as alterações serem tão acentuadas que a pele se apresenta tensa, vermelha ou preta, com equimoses e sufusões, não sendo rara a observação de uma linha delimitando a parte infectada da sadia (LOBATO et al., 2013).

Quando a Gangrena Gasosa ou o Carbúnculo Sintomático não são rapidamente controlados, o animal desenvolve toxemia sistêmica e choque; e em ovinos a morte ocorre após 12 a 36 horas (GREGORY et al., 2006; LOBATO et al., 2013).

\section{Necropsia}

Deve-se proceder à necropsia em até seis horas após a morte do animal, pois a maioria dos clostrídios invadem a carcaça rapidamente mascarando os resultados do diagnóstico final (LOBATO et al., 2013).

Quando a necropsia é realizada, os tecidos subcutâneo, intermuscular e os demais tecidos próximos ao local afetado apresentam-se distendidos por um fluido edematoso amarelo, parcialmente hemorrágico e com bolhas de gás. A musculatura apresenta-se intensamente hemorrágica, enfisematosa e com áreas cinza, indicativas de necrose (LOBATO et al., 2013). 
À necropsia também há exsudação de líquido avermelhado e de odor rançoso ao corte, sendo que a musculatura acometida se apresenta ressecada ao centro da lesão. Os linfonodos regionais e os pulmões ficam hiperêmicos e edemaciados e nas cavidades torácica e abdominal há presença de fluido seroso avermelhado. Quando o miocárdio está lesado ocorre pericardite fibrinosa a fibrohemorrágica e trombos murais nas câmaras cardíacas (ARAÚJO, 2010).

\section{Exame Histológico}

Segundo Vargas (2005), o tecido muscular afetado é a principal amostra usada para o diagnóstico do Carbúnculo Sintomático, embora possam ser usados o miocárdio ou fígado. $\mathrm{O}$ material pode ser remetido fresco, resfriado, congelado ou fixado em formalina neutra $10 \%$ (LOBATO et al., 2013).

De acordo com Hulland (1993), o exame histológico apresenta área de necrose proveniente das toxinas bacterianas e do envolvimento vascular, sendo que hemorragias, bolhas de gás e ausência de resposta inflamatória são características do carbúnculo. Para Lobato et al. (2003), histologicamente observam-se fibras musculares difusamente tumefeitas, eosinofílicas, com perda de estriações e/ou difusamente fragmentadas, na presença de bacilos, com infiltração inflamatória variando de ausente a moderada, constituída por neutrófilos. Assis et al. (2005), verificaram ainda presença difusa de bastonestes basofílicos entre os feixes musculares.

\section{Exame Laboratorial/Isolamento do agente}

A identificação do agente tem sido baseada no isolamento, nas características morfológicas e bioquímicas. Entretanto, esses procedimentos são laboriosos, demorados (levam em torno de quatro dias a uma semana para se completar), requerem pessoal treinado e podem incorrer a resultados imprecisos (ASSIS et al., 2001).

Segundo Gomes (2013), o isolamento de Clostridium chaouvoei é difícil, pois deve ser cultivado em meios especiais e ambiente privado de oxigênio e as amostras podem estar contaminadas com outras bactérias anaeróbias, mascarando o C. chauvoei e impedindo o cultivo. Assis et al. (2001) citam que há dificuldade de colheita, envio de amostras e processamento das mesmas no laboratório, pois os clostrídios são extremamente sensíveis ao oxigênio e por isso seu crescimento facilmente é superado por outros microrganismos presentes nas amostras. Muitas ferramentas têm sido desenvolvidas para facilitar a identificação de clostridioses nos laboratórios, porém, também é necessário que sejam pesquisados e aperfeiçoados métodos para facilitar o envio de amostras do campo ao laboratório (FARIAS, 2011). 
O método padrão para detecção de $C$. chauvoei é baseado no cultivo, enviando geralmente ao laboratório tecido muscular esquelético, sendo este o material de eleição para a detecção destes agentes (ASSIS et al., 2010).

O ágar enriquecido com sangue ovino é um dos meios para identificação do C. chauvoei, resultando em colônias circundadas por ampla hemólise, além de produzir esporos subterminais juntamente com numerosas formas pleomórficas vistas ao microscópio por meio de coloração de gram (WALKER, 1990).

Alguns métodos imunológicos podem ser empregados para visualização e identificação da bactéria, como a imunofluorescência direta (IFD), teste que permite a detecção dos agentes por meio de anticorpos marcados (ASSIS et al., 2001). Este é um método rápido e eficiente quando se tem disponível a fluoresceína conjugada ao anticorpo específico para clostrídios, não possibilitando reação cruzada (QUINN et al., 1994).

O emprego da técnica da PCR (Polymerase chain reaction) é capaz de fornecer um diagnóstico rápido e preciso, demonstrando resultado superior quando comparado aos testes com imunofluorescência direta (KUHNERT et al., 1997).

A técnica de estreptavidina-biotina peroxidase (SBP) é eficiente para a determinação da etiologia dos casos de mionecroses a partir de amostras de músculo esquelético, rim, fígado e miocárdio de animais (ASSIS et al., 2010). Para seu uso, amostras de tecido são fixados por imersão em formalina tamponada a $10 \%, \mathrm{pH} 7,2$, durante 24 horas e embebidas em parafina. Para realização da SBP são utilizados kits comerciais e então as amostras são contrastadas com hematoxilina de Harris, cobertas com lamínulas e examinadas sob um microscópio de luz (ASSIS et al., 2005).

O diagnóstico etiológico do Carbúnculo Sintomático é suficiente para um diagnóstico conclusivo e essencial para a adoção de medidas de controle. No entanto, o insucesso no isolamento geralmente ocorre pela dificuldade encontrada pelos médicos veterinários em enviar material de forma correta e em tempo hábil, sendo economicamente inviável para as propriedades rurais (BALDASSI et al., 1985).

\section{CONTROLE}

Devido às características ecológicas dos clostrídios, que fazem parte da microbiota digestiva dos animais e do solo, e pela sua forma de resistência na natureza, a erradicação dos mesmos é praticamente impossível (PINHEIRO et al., 2007). Dessa forma, para garantir o sucesso no controle do Carbúnculo Sintomático, deve-se realizar manejo adequado e vacinação em todos os animais (LOBATO, 2005). 
As medidas que devem ser adotadas em relação ao manejo são medidas como: higiene no momento da vacinação, assepsia do local de aplicação, manejo adequado de carcaças, desinfecção de agulhas e instrumental cirúrgico (LOBATO, 2013). Ainda, deve-se ter o cuidado com a desinfecção de feridas e cortes, pois é uma porta de entrada para o agente (MACHADO, 2008).

Os animais acometidos devem ser rapidamente tratados, devido ao curso superagudo da doença, com administração intravenosa de altas doses de penicilina. As chances de recuperação são maiores para animais no início da infecção ou aqueles cuja lesão muscular não esteja disseminada, mas, em geral, os tratamentos não são bem sucedidos (LOBATO et al., 2013), portanto, mais importante do que o tratamento são as medidas profiláticas associadas à vacinação (GREGORY et al., 2006).

Deve ser estabelecido um programa de vacinação no rebanho e escolher uma vacina que seja eficiente para que o sucesso da imunização ocorra. As apresentações no mercado de vacinas são as monovalentes e polivalentes, sendo que as monovalentes protegem somente para CS, pois são produzidas com o Clostridium chauvoei, enquanto que as polivalentes abrangem outras como o Clostridium perfringes e Clostridium sordelii que garantem proteção contra enteretoxemia (MACHADO, 2008).

A vacina é administrada por via subcutânea e a primeira dose deve ser aplicada aos 60 dias após o nascimento. A segunda dose é aplicada quatro semanas antes do desmame ou no período do desmame. Após a segunda dose deve-se fazer o reforço anualmente (LOBATO et al., 2005). Quando o rebanho é sistemicamente vacinado, os anticorpos colostrais protegem os animais por até 3-4 meses após o nascimento, devendo então a primovacinação ser feita após esse período (LOBATO et al., 2007).

Em casos de surtos, os animais devem ser vacinados ou revacinados. A transferência dos animais para áreas distantes do sítio de contaminação pode ser uma estratégia, porém nem sempre efetiva. Carcaças devem ser incineradas para prevenir a disseminação da bactéria (LOBATO et al., 2005).

\section{CONSIDERAÇÕES FINAIS}

Mesmo com uma grande ocorrência de casos de Carbúnculo Sintomático, o seu diagnóstico, seja através dos sinais clínicos, à necropsia ou por métodos de isolamento em laboratório, é difícil. O Carbúnculo Sintomático é uma doença de curso rápido e seu tratamento dificilmente resulta na convalescência do animal. Dessa forma, as medidas de controle e profilaxia tais quais vacinação e boas práticas de higiene se fazem extremamente importantes 
para manter a sanidade do rebanho quanto às clostridioses, de modo a diminuir os prejuízos e potencializar a produção pecuária, assegurando maior rentabilidade ao produtor.

\section{REFERÊNCIAS}

ARAÚJO R. F.et al. Vaccination protocol and bacterial strain affect the serological response of beef calves against blackleg. Pesquisa Veterinária Brasileira, v. 7, n. 10, p. 554-558, jun. 2010.

ASSIS, R. A.et al. Producción y evaluación de conjugados fluorescentes para diagnóstico de mancha y gangrena gaseosa. Revista de Medicina Veterinária, v. 82, n. 2, p. 68-70, 2001.

ASSIS, R. A.et al. Mionecroses clostridiais bovinas. Arquivos do Instituto Biológico, v. 77, n. 2, p. 331-334, abr./jun., 2010.

ASSIS, R. A.et al. Immunohistochemical detection of Clostridia species in paraffin-embedded tissues of experimentally inoculated guinea pigs. Pesquisa Veterinária Brasileira, v.25, p. 4-8, 2005.

BALDASSI, L.et al. Observações sobre a incidência de gangrena gasosa e carbúnculo sintomático durante 10 anos, 1970-79, no estado de São Paulo. Biológico, v. 51, p. 161-165, 1985.

FARIAS, L. D. A. Carbúnculo Sintomático: Abordagem Diagnóstica e Imunológica. Dissertação de Mestrado, Universidade Federal de Santa Maria, Rio Grande do Sul, p. 20, 2011.

GOMES, M. J. P. Gênero Clostrium spp: Clostrium chauvoei. Universidade Federal do Rio Grande do Sul, 2013.

GREGORY, L.et al. Carbúnculo sintomático: ocorrência, evolução clínica e acompanhamento da recuperação de bovino acometido de "Manqueira". Arquivos do Instituto Biológico, v. 73, n. 2, p. 243-246, 2006.

HULLAND, T. J. Muscle and tendons. Pathology of domestic animals, San Diego: Academic Press, 1993.

KUHNERT, P.et al. Identification of Clostridium chauvoei in cultures and clinical material from blackleg using PCR. Veterinary Microbiology, v. 57, n. 2-3, p. 291-298, 1997.

LOBATO, F. C. F.; ASSIS, R. A. Clostridioses dos animais. II Simpósio Mineiro de Buiatria, Belo Horizonte, MG. Out., 2005.

LOBATO F.C.F.; SALVARANI, F. M.; ASSIS, R. A. Clostridioses dos pequenos ruminantes. Revista Portuguesa de Ciências Veterinárias, v. 34, p.102-23, 2007.

LOBATO, F. C. F.et al. Clostridioses dos Animais de Produção. Veterinária e Zootecnia, v. 20, p.29-48, 2013. 
MACHADO, M. B. D. Carbúnculo Sintomático em bovinos. Tese (Especialização de Clínica médica e Sanidade de Grandes Animais). Universidade Castelo Branco, Rio de Janeiro, nov., 2008 .

MAPA, Ministério da Agricultura, Pecuária e Abastecimento. Informes semestrais e anuais OIEBrasil 2005 a 2011. Disponível em: <http://www.agricultura.gov.br/animal/sanidadeanimal/informacoes-epidemiologicas>. Acesso em: 28 de nov. de 2013.

PINHEIRO, R. R.; ALVES, F. S. F.; ANDRIOLI, A. Enfermidades Infeciosas de Pequenos Ruminantes: Epidemiologia, Impactos Econômicos, Prevenção e Controle: Uma Revisão.

Revista Brasileira de Higiene e Sanidade Animal, v. 01. n. 01, p. 44-66, 2007.

QUINN, P. J.et al. Clostridium species p.191-208. Clinical Veterinary Microbiology. London: Wolfe, p. 649, 1994.

ROGERS, G. M.; SWECKER JR, W. S. Clostridial vaccines: timing and quality assurance. Food Animal, p. 278-285, 1997.

STERNE, M. Clostridial infections. British Veterinary Journal, v. 137, p. 443-454,1981.

WALKER, P.D. Clostridium. Diagnostic procedures in veterinary bacteriology and mycology. 5.ed. New York: Academic Press, cap.19, p.620, 1990. 